After Nationalism 



\section{After Nationalism}

Being American in an Age of Division

\section{Samuel Goldman}

\section{PENN}

UNIVERSITY OF PENNSYLVANIA PRESS

PHILADELPHIA 
Copyright $\odot 2021$ University of Pennsylvania Press

All rights reserved. Except for brief quotations used for purposes of review or scholarly citation, none of this book may be reproduced in any form by any means without written permission from the publisher.

Published by

University of Pennsylvania Press

Philadelphia, Pennsylvania 19104-4112

www.upenn.edu/pennpress

Printed in the United States of America on acid-free paper

$\begin{array}{llllllllll}10 & 9 & 8 & 7 & 6 & 5 & 4 & 3 & 2 & 1\end{array}$

Library of Congress Cataloging-in-Publication Data

Names: Goldman, Samuel, author.

Title: After nationalism : being American in an age of division / Samuel Goldman.

Description: 1st edition. | Philadelphia : University of Pennsylvania Press, [2021] | Includes bibliographical references and index. Identifiers: LCCN 2020043577 | ISBN 9780812251647 (hardcover) Subjects: LCSH: Nationalism-United States. | National characteristics, American. | Cultural pluralism-United States. | United States-Civilization-1970-

Classification: LCC E169.1 .G633 2021 | DDC 320.540973-dc23

LC record available at https://lccn.loc.gov/2020043577 